\title{
底面酸素輸送に対するVortex sheddingの影響 \\ - 理論解と循環水路実験結果との比較 - \\ EFFECTS OF VORTEX SHEDDING ON THE BENTHIC OXYGEN TRANSFER \\ - A COMPARISON BETWEEN ANALYTICAL CALCULATION AND EXPERIMENT -
}

\author{
井上徹教 1 ・中村由行 2 \\ Tetsunori INOUE and Yoshiyuki NAKAMURA \\ 1正会員 工博 港湾空港技術研究所 沿岸環境研究領域（ T239-0826 神奈川県横須賀市長瀬3-1-1） \\ 2正会員 工博 港湾空港技術研究所（同上）
}

\begin{abstract}
A laboratory experiment regarding diffusive oxygen transfer rate at rough sediment surface was conducted to compare with the analytical calculation, considering vortex shedding in the benthic boundary layer and biochemical reactions in the sediment. The reproducibility of the experimental results by analytical calculation was considerably improved by including terms for vortex shedding frequency in the diffusive boundary layer between the roughness elements and for non-steady variations in the diffusive oxygen transfer rate due to instantaneous changes in oxygen concentration in the flushed region. A simple method to estimate enhancement effect for Stanton number, which is a non-dimensional diffusive transfer rate relative to the mean velocity, the mean concentration in the bulk region, and the mean concentration at the sediment-water interface, caused by occurrences of vortex shedding was also presented.
\end{abstract}

Key Words : Benthic oxygen transfer, surface roughness, hydrodynamic control, vortex shedding

\section{1. はじめに}

酸素は水圈の生化学的反灾において用いられる最も有

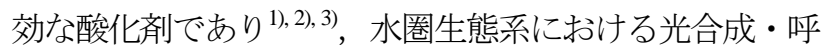
吸・物質の酸化等を通して, 物質循環において支配的な 役割を担う最も重要な物質の一つであると考えられる. 従って, 水圈環境中での生態系や代謝活性, 物質循環を 理解する上では，水柱における酸素収支を定量化するこ とが必要である.

富栄養化した水域での水柱における酸素消費について は，堆積物による酸素消費 (sediment oxygen demand, SOD, 本稿では水・堆積物界面での単位面積当たりの酸 素輸送速度として定義する）が主たる役割を担っている と考えられる33. 4). 堆積物中の酸素濃度はそこでの酸化 還元状態に多大な影響を与える重要なパラメーターであ り, 水・堆積物界面における酸素以外の物質収支にも大 きく影響を及ぼす5)。さらに，特に富栄養化した浅い内 湾や湖においては，SODが酸素収支に果たす役割は底層 の貧酸素化・無酸素化という形で非常に顕著に現れ，そ
こでの底生生物の分布を変化させるなど生態系に大きな 影響を及ぼすため，SODを定量的に評価することは非常 に重要な課題であると考えられている5).

前稿包において，筆者らは水・堆積物界面における酸 素の拡散輸送速度に対する粗度やvortex sheddingの影響 について理論的に検討した。本稿ではInoue and Nakamura ${ }^{7)}$ での検討を踏襲し, 前稿6において得られた 理論解と室内実駼結果との比較を行い考察する. また, 理論解と室内実験結果との差を説明可能な過程として vortex shedding発生周期の影響について検討するととも に, vortex shedding発生直後の非定常的な過程に関する 仮説を述べる.さらに, vortex sheddingの影響に対して, 定常場に対して求められた理論解を簡便に修正寸る方法 を提案する.

\section{2. 循環水路実験}

\section{（1）実験概要}

水・堆積物界面における酸素輸送速度に及ぼす底面粗 
度の影響を検証する目的で，循環式管水路を用いた室内 実験を行った．本実験においては，長さ2.5 m, 高さ15 $\mathrm{cm}$, 幅12.5 cmの矩形断面を持つ管水路を用いた. 水路 床の中央部には長さ100 cm, 深さ10 cmの窪みが設けら れており，現場から採取された堆積物を敷さ詰めること ができる，管路は密閉されており，外気との接触はなく， 酸素のように気液界面での輸送が存在し得る物質につい ても，循環水中での収支をとることができる．管路内の 水はポンプにより循環させることができ，インバーター を用いてポンプの回転速度を制御することで管路内の流 速を変化させることも可能である. さらに，水路床に3 mm角, または $5 \mathrm{~mm}$ 角のアクリル棒を複数設置すること により，積極的に粗度条件を変化させた実験を行うこと も可能となっている

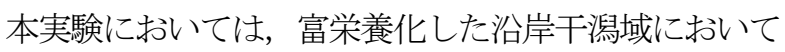
シャベルを用いて表層5 cm程度の堆積物を採取して実験 室に持ち帰り，撹拌して一様化を図った後，実験水路床 に設けた窪みに水路床と等しい高さになるように敷き詰 めた. 水路内には酸素濃度を飽和にした人工海水を注入 し，ポンプの稼働により水路内を循環させた。水温は温

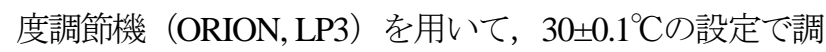
節した. 堆積物中に存在した底生生物は可能な限りピン セットを用いて除去した後，実験を開始した．管路内堆 積物上の流速分布は，別途レーザードップラー流速計

（TSI, Model9710）を用いて詳細に測定しており，対数 測分布を用いて平均流速と摩擦速度や相当砂粒粗度との 関係を得た．実験条件を表-1に示す.

\section{（2） SOD測定}

実験期間中は暗幕で実験装置全体を覆い，光合成によ る酸素濃度の変化を避けた，循環水中の酸素濃度は，水 路下流部に設置した溶存酸素濃度計（TOA Corp., DO25A）を用いて測定した。溶存酸素濃度計の校正は，各 実験前後に採水した循環水の酸素濃度をウィンクラー法 で測定した值と比較することで行った．各実験終了後は 循環水を空気曝気することで酸素濃度を増加させ，その 後次の実験を開始した.

循環水は循環水路に設けたサンプリングコックを用い て，空気に暴露することなく約1日間隔で採取した。循 環水自身の酸素消費速度は，BOD測定に準じた方法によ

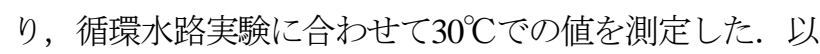
上より得られたデータを用いて，循環水路中の酸素濃度 の減少率から次式によりSODの算定を行った.

$$
V\left\{\frac{d C_{O}(z=\infty)}{d t}\right\}=-S O D \cdot A-r_{w} \cdot V
$$

ここで, $V$ は循環水路内 $の$ 容積, $C_{O}(z=\infty)$ は循環水中の 酸素濃度, $t$ は時間, $A$ は堆積物の表面積, $r_{w}$ は循環水単 位体積当たりの酸素消費速度を表す。

実験終了後は，両端を切り落としたシリンジを用いて，

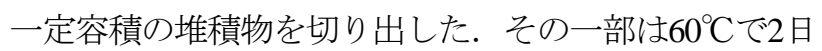
間乾燥させ，前後の重量変化から間隙水密度を考慮して 間隙率 $\phi$ 算出した。得られた間隙率から, 次式を用い て堆積物中での見かけの拡散係数D寺計算した.

$$
D_{s}=\phi^{m-1} D_{0}
$$

ここで， $m$ は数值定数（=3, Ullman and Aller $\left.{ }^{9)}\right) ， D_{0}$ は分

表-1 実験条件一覧

\begin{tabular}{|c|c|c|c|c|c|c|c|c|c|}
\hline \multirow{2}{*}{ 粗度条件 } & \multirow{2}{*}{\multicolumn{3}{|c|}{$\begin{array}{l}\text { 循環水酸素濃度 } \\
C_{O}(\mathrm{z}=\infty)\left(\mathrm{mg} \mathrm{L}^{-1}\right)\end{array}$}} & \multirow{2}{*}{\multicolumn{3}{|c|}{$\begin{array}{c}\text { 界面酸素濃度 } \\
C_{O}(\mathrm{z}=0)\left(\mathrm{mg} \mathrm{L}^{-1}\right) \\
\end{array}$}} & \multirow{3}{*}{$\begin{array}{c}\text { 平均流速 } \\
\bar{u}\left(\mathrm{~cm} \mathrm{~s}^{-1}\right) \\
3.7\end{array}$} & \multirow{3}{*}{$\begin{array}{l}R e * \\
8.4\end{array}$} & \multirow{3}{*}{$\frac{C_{f}}{0.076}$} \\
\hline & & & & & & & & & \\
\hline $\begin{array}{l}\text { 無し } \\
\end{array}$ & 5.1 & $\sim$ & 5.5 & 5.1 & $\sim \sim$ & 5.5 & & & \\
\hline $\begin{array}{l}\text { 無し } \\
\end{array}$ & 5.3 & $\sim$ & 5.6 & 5.3 & $\sim$ & 5.6 & 5.6 & 8.2 & 0.031 \\
\hline $\begin{array}{l}\text { 無し } \\
\end{array}$ & 5.1 & $\sim$ & 7.5 & 5.1 & $\sim$ & 7.5 & 7.0 & 11.2 & 0.032 \\
\hline 無し & 6.2 & $\sim$ & 6.5 & 6.2 & $\sim$ & 6.5 & 9.0 & 12.3 & 0.031 \\
\hline $\begin{array}{ll}\text { 無し } \\
\end{array}$ & 6.5 & $\sim$ & 6.7 & 6.5 & $\sim$ & 6.7 & 10.4 & 12.5 & 0.030 \\
\hline $3 \mathrm{~mm}$ & 5.5 & $\sim$ & 6.5 & 5.5 & $\sim$ & 6.5 & 1.2 & 10.2 & 0.055 \\
\hline $3 \mathrm{~mm}$ & 7.0 & $\sim$ & 7.5 & 7.0 & $\sim$ & 7.5 & 3.1 & 39.1 & 0.102 \\
\hline $3 \mathrm{~mm}$ & 5.9 & $\sim$ & 7.2 & 5.9 & $\sim$ & 7.2 & 5.0 & 77.6 & 0.102 \\
\hline $3 \mathrm{~mm}$ & 5.8 & $\sim$ & 6.1 & 5.8 & $\sim$ & 6.1 & 6.2 & 33.7 & 0.055 \\
\hline $3 \mathrm{~mm}$ & 6.8 & $\sim$ & 7.8 & 6.8 & $\sim$ & 7.8 & 9.3 & 319.4 & 0.167 \\
\hline $3 \mathrm{~mm}$ & 5.4 & $\sim$ & 7.1 & 5.4 & $\sim$ & 7.1 & 9.4 & 146.8 & 0.266 \\
\hline $5 \mathrm{~mm}$ & 7.7 & $\sim$ & 8.1 & 7.7 & $\sim$ & 8.1 & 1.2 & 14.2 & 0.084 \\
\hline $5 \mathrm{~mm}$ & 7.2 & $\sim$ & 7.6 & 7.2 & $\sim$ & 7.6 & 3.5 & 36.3 & 0.089 \\
\hline $5 \mathrm{~mm}$ & 6.1 & $\sim$ & 6.9 & 6.1 & $\sim$ & 6.9 & 4.8 & 48.6 & 0.117 \\
\hline $5 \mathrm{~mm}$ & 6.2 & $\sim$ & 7.3 & 6.2 & $\sim$ & 7.3 & 7.1 & 56.6 & 0.083 \\
\hline $5 \mathrm{~mm}$ & 6.8 & $\sim$ & 7.3 & 6.8 & $\sim$ & 7.3 & 7.6 & 188.9 & 0.251 \\
\hline $5 \mathrm{~mm}$ & 5.9 & $\sim$ & 6.7 & 5.9 & $\sim$ & 6.7 & 11.3 & 252.7 & 0.199 \\
\hline
\end{tabular}

(界面酸素濃度については, 式(5)から求めた值を示している。) 
子拡散係数（循環水路実験結果との比較に際しては $D_{0}=$ $2.66 \times 10^{-5} \mathrm{~cm}^{2} \mathrm{~s}^{-1}$ と設定）を表す.

残りの堆積物は既知容積の密閉容器中で循環水に懸濁 させ，そこでの酸素濃度の低下率から堆積物単位体積当 たりの酸素消費速度 $r_{s}$ を算定した ${ }^{10)}$ 。これらの結果は, 以下に述べる理論解の算出過程において採用した.

\section{3. 理論解との比較と考察}

井上・中村( ${ }^{6}$ は水・堆積物界面における酸素輸送に関 して粗度を考慮した理論解析を行い, 酸素輸送速度 $S O D$ の無次元量を表すスタントン数Stを以下のように導出し ている.

$$
\begin{aligned}
& S t=\frac{S O D}{\bar{u}\left\{C_{o}(z=\infty)-C_{o}(z=0)\right\}} \\
& =\left(\frac{C_{f}}{2}\right)^{\frac{1}{2}}\left\{\frac{\left(R e_{*} \cdot S C\right)^{\frac{1}{2}}}{C_{1}}+A\left(z_{+}=\infty\right)\right\}^{-1} \\
& A\left(z_{+}=\infty\right) \equiv \int_{z_{0+}}^{\infty} \frac{1}{\left(\frac{1}{S C}+D_{z t+}\right)} d z_{+} \\
& C_{O}(z=0)=\frac{D_{s} r_{s}}{S t^{2} \bar{u}^{2}}+C_{O}(z=\infty) \\
& -\sqrt{\left\{\frac{D_{s} r_{s}}{S t^{2} \bar{u}^{2}}+C_{O}(z=\infty)\right\}^{2}-C_{O}(z=\infty)^{2}}
\end{aligned}
$$

ここで， $\bar{u}$ はバルク領域における水平方向の平均流速, $C_{O}(\mathrm{z}=0)$ は水・堆積物界面における酸素濃度, $C_{f}$ は底面 抵抗係数, $R e_{*}$ は摩擦速度 $u_{*}$ と相当砂粒粗度 $k_{s}$ から求始 れる粗さのレイノルズ数, Scはシュミット数（循環水路 実験結果との比較に際してはSC $=301$ と設定）， $c_{1}$ は semi-stagnant film内の水塊の更新周期に関連寸る定数, $z$ は水・堆積物界面からの距離（界面を 0 , 上向きを正と する）， $z_{0}$ は粗度要素間に存在するsemi-stagnant film厚さ， $D_{z t}$ は乱流拡散係数, 添字"+" "は摩擦速度 $u_{*}$ と動粘性係数 $v$ による無次元量を表す.

本稿では, 底面抵抗係数 $C_{f}$ は次式から計算した。

$$
C_{f}=2 u_{*}^{2} / \bar{u}^{2}
$$

また，乱流拡散係数 $D_{t t}$ の鉛直分布についてはInoue and Nakamura》音踏襲し, 次式から計算した.

$$
D_{z t+}=\frac{\left\{\kappa Z_{+}\left(1-\frac{z_{+}}{\delta_{+}}\right)^{2}-2\right\}+\left[\left\{\kappa Z_{+}\left(1-\frac{z_{+}}{\delta_{+}}\right)^{2}-2\right\}^{2}-4\right]^{\frac{1}{2}}}{2}
$$

(at $\left.\mathrm{Z}_{+}>10\right)$

$$
D_{\text {zt+ }}=K z_{+}^{3} \quad\left(\text { at } \mathrm{z}_{+}<10\right)
$$

ここで，Кはカルマン常数 (=0.4, Grant and Madsen $\left.{ }^{11)}\right)$, $\delta$ は境界層厚さ (循環水路実験との比較においては管路 高さの $1 / 2$ とした），Kは数值定数 $\left(=10^{-3}\right.$, Dade $\left.^{12)}\right)$ を表 す. 以下ではこれらから得られた理論解と実験結果との 比較を行う。

なお，上記理論は発達した境界層を対象としており， 本実験（水路長さが $2.5 \mathrm{~m}$ ）ではこの条件を満たしてい ない可能性がある. Higashino and Stefan ${ }^{13}$ は, 堆積物部 分の流下方向の長さがSOD測定に及ぼす影響について解 析的に検討しており，その結果を本実験条件に適用寸る と平均流速が約 $6 \mathrm{~cm} \mathrm{~s}^{-1}$ 以上の場合にSOD測定に及ぼす影 響は無視できるという結論が得られる．本実験条件では この流速以下での実験結果も含まれるため, $u_{*}$ および $R e_{*}$ の空間分布を測定し, それらの水路内での平均的な 值を解析に用いることで理論解との整合を図った.

\section{（1） $c_{F}=1$ とした場合の理論解と実駼結果との比較}

図-1 (a) は，Dade ${ }^{12)}$ などに見られるように $c_{1}=1$ とした 場合の上記理論の定常解と実験結果との関係を示してい る. 理論解は実験結果を約 $67.6 \%$ 程度に過小評価してお り, それらの相関も $R^{2}=0.409$ と再現性も低い結果と なっていることがわかる.ここでは，これらの問題の原 因として, 上記のモデル化においては唯一論理的な考察 を元に決定されていないパラメーターである $c_{1}$ の取り扱 いに注目寸る，そこで以下では，第一の問題として粗度 要素間の水塊の交換周期について検討を行う.

またもう一つの問題として, Inoue et al. ${ }^{14}$ により導入さ れた, 直上水中の溶存物質濃度の急激な変化は水・堆積 物界面における溶存物質輸送速度の増大を招くという, 非定常現象に関する概念が挙げられる. そこで第二の問 題として, 底面上に位置する粗度要素間の水塊の更新直 後における水・堆積物界面での酸素輸送速度の非定常的 な変動の影響について検討する.

\section{（2）粗度要素間の水塊交換周期の影響}

ここでは，第一の問題として考えられる，粗度要素間 の水塊の交換率 (交換周期 $S$ ) について検討寸る. Corino and Brodkey ${ }^{15}$ は固体壁面付近の乱流における流動測定を 行なった. その結果, 壁面近傍の粘性底層は小さなス ケールの流速変動により継続的に乱されており, 壁面の 遠方から粘性底層内一と浸透する流体要素により準周期 的に更新されていることが示された。このような現象 は” vortex shedding”として知られており，これが壁面 における熱や物質輸送を支配する重要なパラメーターと なる． 既に前稿のにおいて， $c_{1}$ にいては次式のように 簡単な粗さのレイノルズ数Re $e_{*}$ の関数として表すことが 可能であることが示されている.

$$
c_{1}=0.094 R e_{*}^{1 / 2}
$$

図-1 (b) に式(9)により定量的に評価された $c_{1}$ を用いて 
計算された理論解と本実験結果との比較を示す。この場 合でも，計算結果は総体的に実験結果の65.8\%程度の值 をとっており，依然として理論解は実験結果を過小評価 する結果となっている，しかし，それらの関係における 決定係数は $R^{2}=0.753$ となっており，この点については かなりの改善がみられる.

この結果より，図-1 (a)にみられたような理論解と実 験結果とのばらつきは，上述のモデル化の過程において 粗度要素間の水塊交換の周期（vortex sheddingの発生周 期）を合理的な考察の元に決定していなかったことが原 因であると結論した.

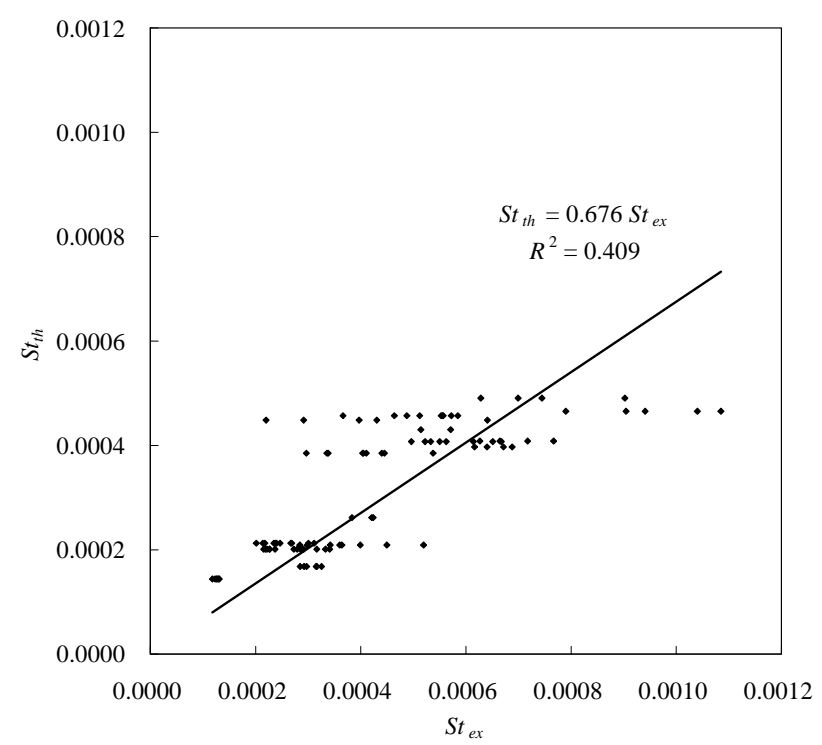

(a) $c_{1}=1$ として非定常過程を考慮しない場合

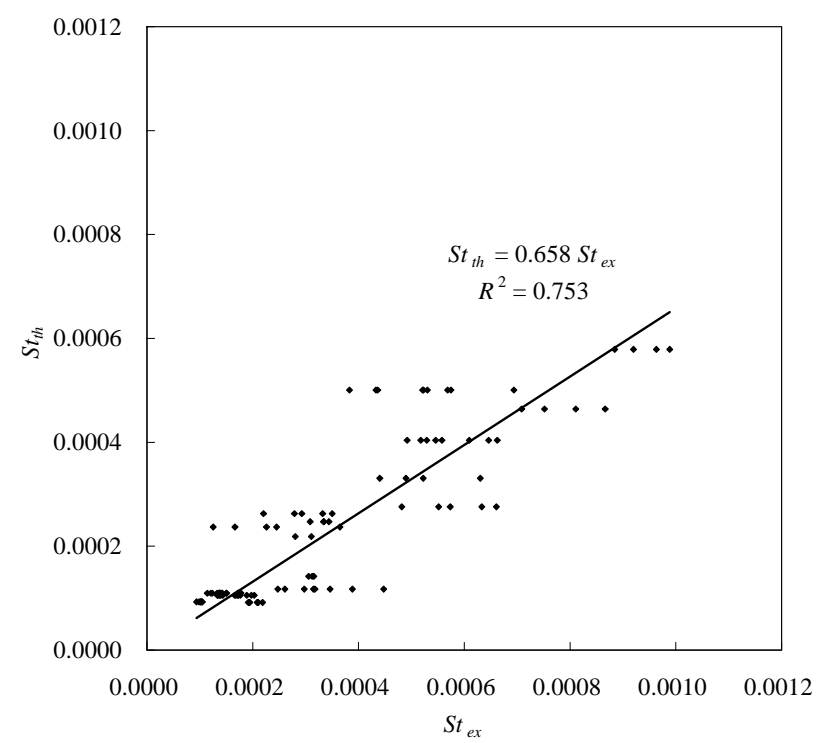

（b）水塊交換周期を定式化し 非定常過程を考慮しない場合

\section{（3） vortex shedding直後の非定常過程}

次に, 第二の問題として粗度要素間の水塊の更新直後 における水・堆積物界面での酸素輸送速度の非定常的な 変動の影響について検討する. Black ${ }^{16)}$ は壁面近傍での乱 流場において有用なスケール則を導入し，多数の実験結 果からvortex sheddingの発生周期について検討している。

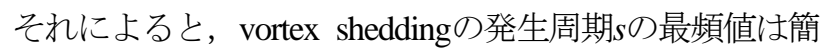
単な摩擦速度の関数として次式により与えられる.

$$
s=112 \frac{v}{u_{*}^{2}}
$$

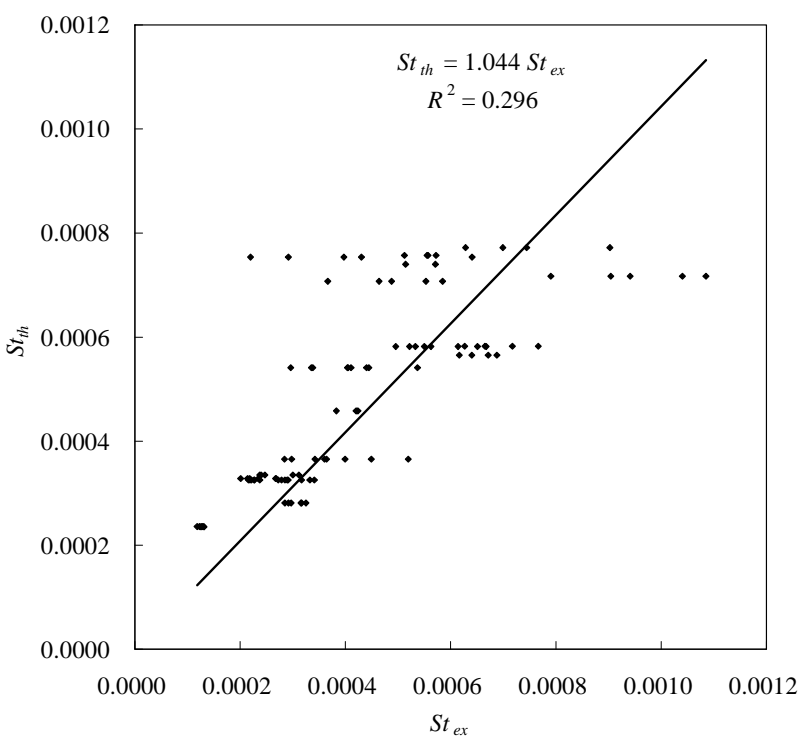

（c） $c_{1}=1$ として非定常過程を考慮した場合

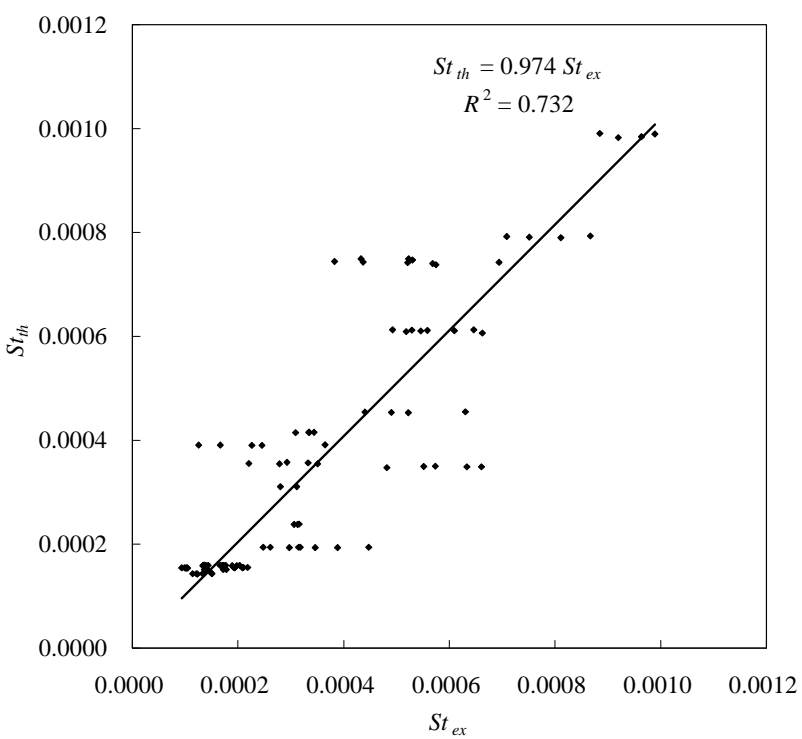

（d）水塊交換周期を定式化し 非定常過程を考慮した場合

図-1 理論解と実験結果との比較 
一方，壁面摩擦により発生した渦は，境界層内部の水 塊の内，壁面からある一定の距離以上の水塊を更新する ものと仮定する．ここではこの距離を拡散境界層厚さ $\delta_{d}$ の $\beta$ 倍と仮定し, 壁面から $\beta \delta_{d}$ 以上の距離にある水塊が更

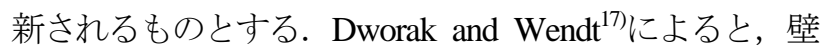
面摩擦により発生した渦は境界層内の水塊を更新するが, その範囲は壁面からの距離が拡散境界層厚さ $\delta_{d} の 30-50 \%$ の位置より上部であると結論している。そこで本稿では, 壁面からの距離が拡散境界層厚さ $\delta_{d}$ の $40 \%$ の位置から上 部が壁面摩擦によって発生したvortex sheddingにより更 新されるものと考え, $\beta=0.4$ とした.

本節ではこれらの值を用い，また $c_{1}=1$ とした場合の， vortex sheddingが準定常的に発生している期間について の非定常計算の結果を示す.この場合， $c_{1}$ についも式 (9)により定量的に評価することが可能である. しかし, 本節においてはvortex sheddingの発生周期 $s$ 定量的に評 価することによる効果と, vortex sheddingの発生直後の 非定常過程を考慮することによる効果を区別して検討す ることを目的として，ここでは $c_{1}=1$ を採用することと する. これら双方を取り入れた計算結果については次節 で示す.

これらの計算においては，まずそれぞれの計算条件に 対する酸素濃度分布を求めておく. その後, 壁面からの 距離が $\beta \delta_{d}$ (本稿では拡散境界層厚さ $\delta_{d} \sigma 40 \%$ の位置）よ り上部については，バルク領域の酸素濃度で置換したも のを酸素濃度分布の初期条件として与えた。

これらの計算結果から得られた準定常的な期間におけ る酸素輸送速度の平均值，および本実験結果との比較を 図-1 (c) に示す. この場合，計算結果は平均的に実験結 果を $4.4 \%$ 程度過大評価する結果となっているが，図一 1 (a)または (b)にみられた計算結果と比較して，その定 量的評価においては著しく改善された結果となっている. しかし，それらの関係における決定係数は $R^{2}=0.296$ と なっており，この点については依然として改善がみられ ない.

この結果より，図-1 (a)または (b)にみられたような理 論解による過小評価は，上述のモデル化の過程において vortex sheddingの発生直後における拡散輸送速度の非定 常的な变化に関する考察を行っていなかったことが原因 であると結論した。

\section{（4）水塊の交換周期の定式化とvortex shedding直後の}

\section{非定常過程との組み合わせ}

上記までの考察を元に, semi-stagnant film内の水塊の 更新周期に関連する定数 $c_{1}$ を式(9)で定量的に評価し，さ らにvortex shedding発生が準定常的に発生している期間 における非定常過程も考慮して行った計算結果と，本実 験結果との比較を図-1 (d) に示す. これをみると, 計算 結果は実験結果を定量的かつ精度良く再現していること
がわかる. すなわち図-1 (a)または (b)においてみられた 計算結果の過小評価傾向は改善されており, その平均的 な誤差は2.6\%となっている.さらに，図-1(a)または(c) においてみられた, 理論解のばらつきについても改善が みられ，決定係数は $R^{2}=0.732$ となっている.

これらの考察により, 理論解による実験結果の再現性 は，粗度要素間のキャビティー内における水塊の交換周 期を定量的に評価すること，およびその水塊交換により 拡散境界層中の酸素濃度が急変し水・堆積物界面におけ る拡散輸送が非定常的に変化することを考慮することに よって，著しく改善されることが示された.

\section{(5) 非定常効果によるスタントン数の増幅係数}

上述の非定常過程を考慮した数值計算は非常に煩雑で, 水・堆積物界面における酸素輸送速度を定量化する上で 実用的であるとは言い難い，そこで本節では，上記の非 定常過程を考慮することによるスタントン数の増幅効果 を簡便に定量化し，定常解を修正する係数を提案する.

図-2に摩擦速度と上記の非定常過程を考慮することに よるスタントン数の増幅係数 $F$ との関係を示す.ただし, ここでは本室内実験条件を元に計算された值のみを示し ており，ここでの議論はその実験条件の範囲内 $(0.2 \mathrm{~cm}$ $\left.\mathrm{s}^{-1}<u_{*}<3.6 \mathrm{~cm} \mathrm{~s}^{-1}\right)$ でのみ適用されるものであることに 注意されたい. 図-2から, 上述の条件の範囲内において は, 摩擦速度の増加に伴いスタントン数の増幅係数Fは 単調に減少していることがわかる。これは摩擦速度の増 加に伴い，酸素消費の律速過程が境界層中での拡散から 堆積物内部での酸素消費へと遷移するためであると考え られる.この増幅係数Fの変動は, 摩擦速度の二次関数 となる簡単な回帰式で表現可能である.

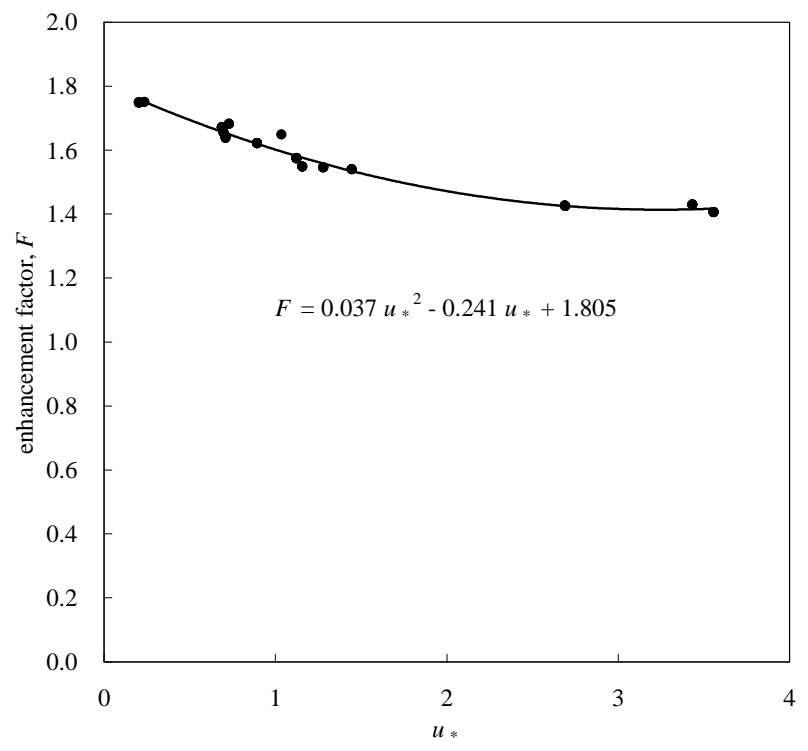

図-2 摩擦速度と非定常過程を考慮することによる スタントン数の増幅係数 $F$ との関係 


$$
\begin{gathered}
F=0.037 u_{*}^{2}-0.241 u_{*}+1.805 \\
\left(0.2 \mathrm{~cm} \mathrm{~s}^{-1}<u_{*}<3.6 \mathrm{~cm} \mathrm{~s}^{-1}\right)
\end{gathered}
$$

一方, スタントン数の増幅係数 $F$ と相当砂粒粗度や他 のパラメーターとの間には明瞭な関係は見られなかった。 上述の非定常過程を考慮した数值計算は非常に煩雑で, 実用的ではないが，底面摩擦の情報を基に，式(11)を用 いることによって非定常過程を考慮せずに求めたスタン トン数を合理的に修正することが可能となる.

\section{4. おわりに}

本稿では，水理学的に粗面であると判断される水・堆 積物界面における酸素の拡散輸送速度について循環式管 水路を用いた室内実験を行い，前項6において提唱した 理論モデルとの比較を行った. その結果, 粗度要素間の キャビティー内における水塊の交換（vortex shedding） の発生周期, および水塊の交換に伴う拡散境界層内の酸 素濃度の急变による酸素拡散輸送の非定常的な変動が共 に重要な現象であることが示された. vortex sheddingの 発生周期を定量的に評価することは，スタントン数を計 算する上で，そのばらつきを低減させることに対して有 効である．また，非定常過程を考慮に入れることにより， 拡散輸送速度の増幅効果を再現することが可能となり， より精度の高い評価には必要不可欠な概念であることが 示された.

今後は, 図-2で示したスタントン数の増幅係数と摩擦 速度との関係において，上述した条件範囲以外の場合で の適用の可否について検討したい. また，本稿において 述べた非定常過程については，その現象自体は実験的に 測定されておらず，仮説の段階にすぎない．この点につ いても，本実験装置を改良し， vortex shedding直後の 水・堆積物界面近傍の酸素濃度分布の変動について実証 に耐え得る測定を行いたい.

謝辞 : 本実験の遂行に際しては, 九州大学大学院環境流 体力学研究室の諸氏の協力を得た. 記して感謝の意を表 します.

\section{参考文献}

1) Bakker, J.F. and Helder, W.: Skagerrak (northeastern North Sea) oxygen microprofiles and porewater chemistry in sediments, Mar. Geol., Vol.111, pp.299-321, 1993.

2) Glud, R.N., Gundersen, J.K., Jørgensen, B.B., Revsbech, N.P. and Schulz, H.D.: Diffusive and total oxygen uptake of deep-sea sediments in the eastern South Atlantic Ocean: in situ and laboratory measurements, Deep-Sea Res., Vol.41, pp.1767-1788, 1994.

3) Steinberger, N. and Hondzo, M.: Diffusional mass transfer at sediment-water interface, J. Envir. Eng., Vol.125, pp.192-200, 1999.

4) Nakamura, Y. and Stefan, H.G.: Effect of flow velocity on sediment oxygen demand: Theory, J. Envir. Eng., Vol.120, pp.996-1016, 1994.

5) Slomp, C.P., Malschaert, J.F.P. and Raaphorst, W.V.: The role of adsorption in sediment-water exchange of phosphate in North Sea continental margin sediment, Limnol. Oceanogr., Vol.43, pp.832846, 1998.

6) 井上徹教, 中村由行 : 底面酸素輸送に対する粗度の影響非定常過程および生化学的過程の重要性 -, 水工学論文集, Vol.55, pp.1531-1536, 2011.

7) Inoue, T. and Nakamura, Y.: Effects of hydrodynamic conditions on DO Transfer at a rough sediment surface, J. Envir. Eng., Vol.137, pp.28-37, 2011.

8) Inoue, T. and Nakamura, Y.: Effects of hydrodynamic conditions on sediment oxygen demand: Experimental study based on three methods, J. Envir. Eng., Vol.135, pp.1161-1170, 2009.

9) Ullman, W.J. and Aller, R.C.: Diffusion coefficients in nearshore marine sediments, Limnol. Oceanogr., Vol.27, pp.552-556, 1982.

10) 細井由彦, 村上仁士, 上月康則: 底泥による酸素消費に関寸 る研究, 土木学会論文集, Vol.456/II, pp.83-92, 1992.

11) Grant, W.D. and Madsen, O.S.: The continental-shelf bottom boundary layer, Ann. Rev. Fluid Mech., Vol.18, pp.265-305, 1986.

12) Dade, W.B.: Near-bed turbulence and hydrodynamic control of diffusional mass transfer at the sea floor, Limnol. Oceanogr., Vol.38, pp.52-69, 1993.

13) Higashino, M. and Stefan, H.G.: Oxygen demand by a sediment bed of finite length, J. Envir. Eng., Vol.131, pp.350-358, 2005.

14) Inoue, T., Nakamura, Y. and Adachi, Y.: Non-steady variations of SOD and phosphate release rate due to changes in the quality of the overlying water, Wat. Sci. Tech., Vol.42, pp.265-272, 2000.

15) Corino, E.R. and Brodkey, R.S.: A visual investigation of wall region in turbulent flow, J. Fluid Mech., Vol.37, pp.1-30, 1969.

16) Black, T.J.: An analytical study of the measured wall pressure field under supersonic turbulent boundary layers, NASA Contractor Report, CR-888, 1968.

17) Dworak, R. and Wendt H.: Stochastic fluctuations of mass transport through turbulent boundary layers, Berichte der BunsenGesellschaft für Physikalische Chemie, Vol.81, pp.864-869, 1977

(2011. 9. 30受付) 